\title{
Appraisal of Managerial Skills of Business Operators in Anambra State
}

\author{
Nwankwo Leopold Arinze \\ Department of Business Administration and Management, School of Business, Federal Polytechnic, Oko, Anambra State, Nigeria
}

\begin{abstract}
Business operators that have good managerial skills are more likely to survive than those that do not have. Accordingly, the main purpose of this study was to appraise extent of managerial skills among business operators in Anambra State. The study was guided by one research question and one hypothesis. The descriptive survey design was adopted. The population of the study comprised 161 personnel managers in the 161 industries in Anambra State. The whole population was studied. A researcher developed instrument duly validated by experts was used for data collection. The reliability of the instrument was determined by administrating twenty (20) copies of the instrument on 20 personnel managers in Enugu State. Using the Chronbach Alpha, the reliability index of the instrument was found to be 0.82 . The researcher and three assistants' distributed copies of the instrument. Mean ratings were used to answer the research question while ANOVA was used in testing the hypothesis. The results indicated that the business operators are less efficient in managerial skills (2.36). Among others, it was recommended that business operators in Anambra State should attend in-service training programmes on managerial skills to enable them perform efficiently in their business.
\end{abstract}

Keywords: Management; Business; Operator; Skill; Manufacture; and Company.

\section{Introduction}

Within the market economy, there are several functions that business operators perform. They produce and sale their goods and services. In order to do this effectively, Arukwe (2000), Harrison (2002) and Anado (2003) identified several skills needed by business operators to effectively carry out their jobs. In recent time, there have been cases of business operators' inability to make use of modern office machines or to offer professional assistance to their employers. A business operator who is not able to operate office machine or relate well with customers may not likely work in a modern office or engage in modern trades. In the same manner performance of their functions is potential to achieving the organizational goals but a business operator who cannot carry out functions attached to his or business or office may not likely contribute in realizing the goals or objectives of the organization or succeed in the business enterprise.

Research findings (Anaelo, 2003; Arukwe, 2000) have indicated that most business operators are not only unable to operate some office machines, some of them lack basic communication skills, and lack of human relation skills. Lack of commitment to the office among business operators has also been identified (Harrison, 2002). In the light of the above, there is need to appraise the managerial skills of business operators in Anambra State. This is necessary because, when people work in an organization, it is expected that, there should be a way of measuring their performances in order to know whether they are actually doing the job for which they were hired and paid. It is equally important that as work is a social activity involving many people that the contributions of the various individuals are identified. This therefore brings to mind the concept of performance appraisal.

According to Obikeze, Obi and Abonyi (2005) performance appraisal is the process of systematically evaluating each employee's job-related strengths, developmental needs and progress towards meeting goals and determining ways to improve the employee's job performance. Performance appraisal from the above conceptualization points to the progress of both the organization and the employees that work towards the achievement of the organizational goals or objectives. Performance appraisal is also seen as a post control technique focusing on the extent to which employees have achieved expected level of work during a specified time or period (Gomez-Mejia, Balkin \& Cardy, 2004). The managerial skills of business operators therefore need to be appraised.

Management as a term refers to the process of getting things done, effectively and efficiently through and with other people. Managerial skills involve those skills needed in the performance of the management functions. Robbins and DeCenzo (2004) observe that there are basically four basic management functions: planning, organizing, leading, and controlling. The performance of the above functions required some measures of skills. Managerial skills explain the ability of the secretary to apply specialized knowledge or expertise on managerial skills. The ability to work well with people, understand their needs, communicate well and motivate others either individually or in group constitutes managerial skills (Katz, 2014).

Managerial skills also entail the mental ability to analyze and diagnose complex situations and broad perspective to contribute to creative problem solving. Managerial skills also involve the secretary's ability to enhance his or her power, build a power based and establish the "right" connections in the organization (Boyatzis 2010). The goal of managerial skills is to integrate productive efforts for proper maximization or utilization of resources and to get optimum output with needed input in goal achievement. The main purpose of this study therefore was to appraise the managerial skills of business operators in Anambra State. 


\section{International Journal of Science and Research (IJSR) \\ ISSN (Online): 2319-7064 \\ Index Copernicus Value (2013): 6.14 | Impact Factor (2015): 6.391}

\section{Research Question}

How efficient are the managerial skills of business operators in Anambra State?

\section{Hypothesis}

Male and female business operators in urban and rural centres do not differ significantly in the mean ratings of their efficiency in managerial skills.

\section{Research Method}

The descriptive survey research design was adopted in this study. Two research questions guided the study. The population of the study comprised 161 respondents made up of the 161 personnel managers in the 161 industries in Anambra State. Data collected from Ministry of Commerce and Industry in September 2015 reveled that there are 161 industries operating in Anambra State. The whole population was studied. A researcher developed instrument duly validated by two experts from business Administration, Nnamdi Azikiwe University, Awka was used for data collection. The instrument was made of two parts " $A$ " and "B". Part "A" was on the background of the respondents while part "B" contained the items on managerial skills. The reliability of the instrument was determined by administrating 10 copies of the instrument on 10 personnel managers in business organizations in Delta State. Using the
Chronbach Alpha, the reliability indices of the two sections of the instrument were found to be 0.82 . The researcher together with two assistants' distributed copies of the instruments. A total of 161 copies were printed and distributed but 160 copies were correctly filled and returned. Mean ratings were used to answer the research questions while ANOVA was used to test the hypothesis at .05 level of significance.

\section{Results}

The demographic information on the respondents is presented in the table 1.

Table 1: Demographic Information on the Respondents

\begin{tabular}{|l|l|l|l|l|}
\hline \multicolumn{2}{|l|}{ URBAN CENTRE } & \multicolumn{2}{l|}{ RURAL CENTRE } & \multirow{2}{*}{ Total } \\
\cline { 1 - 4 } Male & Female & Male & Female & \\
\hline 50 & 57 & 24 & 30 & 161 \\
\hline
\end{tabular}

Source: Anambra State Ministry of Commerce and Industry, September, 2015.

Table 1 shows demographic information on the respondents. According to the table, there are 50male and 57 female personnel managers in the urban centres and 24 male and 30 female personnel managers in the rural areas in Anambra state.

Table 2: Mean(X) Scores of the Respondents on Business Operators' Efficiency in Managerial Skills.

\begin{tabular}{|l|l|l|l|l|l|l|l|}
\hline S/N & Aspects of Managerial Skills & \multicolumn{3}{|c|}{ Mean Ratings } & \multicolumn{3}{|c|}{ RMKS } \\
\hline & & $\begin{array}{l}\text { HE } \\
(4)\end{array}$ & $\begin{array}{l}\mathrm{E} \\
(3)\end{array}$ & $\begin{array}{l}\text { LE } \\
(2)\end{array}$ & $\begin{array}{l}\text { NE } \\
(1)\end{array}$ & $\overline{\mathrm{x}}$ & \\
\hline 1 & Exhibiting leadership qualities in the office & 50 & 198 & 30 & 20 & 2.93 & $\mathrm{E}$ \\
\hline 2 & Being enthusiastic in working in the office & 34 & 42 & 52 & 170 & 1.80 & LE \\
\hline 3 & Striving to complete a given task & 12 & 50 & 53 & 183 & 1.59 & LE \\
\hline 4 & Being innovative in accomplishing a given task in the office; & 37 & 12 & 59 & 190 & 1.65 & LE \\
\hline 5 & Showing interest in the progress of the industry; & 195 & 53 & 29 & 21 & 3.42 & $\mathrm{E}$ \\
\hline 6 & Making sure that each day's job or task is completed. & 28 & 194 & 54 & 22 & 2.77 & $\mathrm{E}$ \\
\hline & Average of mean (x) & & & & & $\mathbf{2 . 3 6}$ & LE \\
\hline
\end{tabular}

Statistical Information for table 2: Rating scales $=4,3,2$ and 1 for HE, E, LE, and NE respectively. HE, E, LE and $\mathrm{NE}=$ Responses for each item.

$\bar{X}=4 \times \underline{\mathrm{HE}+3 \mathrm{XE}+2 \times \mathrm{LE}+1 \times \mathrm{NE}}$ $\mathrm{HE}+\mathrm{E}+\mathrm{LE}+\mathrm{NE}$

Average $\mathrm{X}=\sum \mathrm{X} \overline{\mathrm{X}} \mathrm{N}$

Where $\mathrm{N}=$ Number of items.

The results in table 2 show that the business operators are efficient in showing interest in the progress of the industries (3.42); exhibiting leadership qualities in office (2.93) and making sure that each day's job or task is completed (2.27). They are however less efficient in being enthusiastic in working in the office (1.80); striving to complete a given task (1.59)and being innovative in accomplishing a given task in the office (1.65). On the average, the business operators are less efficient in managerial skills (2.36).

\section{Hypothesis}

Male and female personnel managers in urban and rural centres do not differ significantly in their mean ratings on business operators' efficiency in managerial skills.

Table 3: ANOVA summary of mean ratings of Male and Female Personnel Managers in Urban Centers and Male and Female Personnel Managers in Rural Centers on business operators' efficiency in Managerial Skills

\begin{tabular}{|c|c|c|c|c|c|c|}
\hline $\begin{array}{c}\text { Sources of } \\
\text { Variation }\end{array}$ & $\begin{array}{c}\text { Sum of } \\
\text { Squares }\end{array}$ & Df & $\begin{array}{c}\text { Mean of } \\
\text { squares }\end{array}$ & f-cal & f-crit & P \\
\hline Between Groups & 0.04 & 2 & .02 & & & \\
\hline Within Groups & 7.11 & 159 & .118 & 4.72 & 3.15 & $<.05$ \\
\hline Total & 7.15 & 161 & & & & \\
\hline
\end{tabular}

Decision: $\mathrm{P}<.05$; Reject.

The results in table 3 show that the computed f-value of 4.72 is greater than the critical value of 3.15 . The null hypothesis is therefore rejected at .05 level of significance. 


\section{International Journal of Science and Research (IJSR) \\ ISSN (Online): 2319-7064}

Index Copernicus Value (2013): 6.14 | Impact Factor (2015): 6.391

Table 4: Scheffe Multiple Comparism test for null Hypothesis

\begin{tabular}{|c|c|c|c|c|c|c|c|c|c|}
\hline Compared Groups & Md & f-cal & f-crit & Md & f-cal & f-crit & Md & f-cal & f-crit \\
\hline $\begin{array}{l}\text { Personnel Managers in Urban Centres vs. Personnel Managers in } \\
\text { Rural Centres }\end{array}$ & .26 & .13 & \multirow{3}{*}{3.55} & .24 & .32 & \multirow[t]{3}{*}{3.55} & 17 & .99 & \multirow{3}{*}{3.55} \\
\hline Within Groups & .11 & .66 & & .12 & .17 & & .04 & .99 & \\
\hline Male vs. Female Personnel Managers & .15 & .5 & & .12 & .15 & & .2 & .79 & \\
\hline
\end{tabular}

The results presented in table 4 indicate that all the computed f-values are far less than the critical f-value of 3.55. The conclusion here is that there is no significant difference among the means of each of the groups compared.

\section{Summary of Findings}

Based on the results of data analysis, the summary of major findings are as follows:

1) Personnel managers in the manufacturing industries in Anambra State perceived the business operators as not efficient in managerial skills;

2) Male and female personnel managers in manufacturing industries urban and rural centres in Anambra State do not differ significantly in their mean ratings on business operators' efficiency in managerial skills.

\section{Efficiency of the Personnel Managers in Managerial Skills}

The presentation and analysis of data relating to research question one and hypothesis one indicated that the business operators are efficient in some managerial skills and inefficient in some others. In table two specifically, it is shown that the business operators are efficient in showing interest in the progress of the industries (3.42); exhibiting leadership qualities in office (2.93) and making sure that each day's job or task is completed (2.27). They are however less efficient in being enthusiastic in working in the office (1.80); striving to complete a given task (1.59)and being innovative in accomplishing a given task in the office (1.65). On the average, the business operators are less efficient in managerial skills (2.36).

The above findings confirm an earlier study by Ryan (2007) which found that some business/operators are less enthusiastic to work, are inefficient in making decisions without asking for direction and as a result, seek to improve their abilities through reading managerial handbooks, periodicals and other related literature or materials. This corroborated the recommendation by Pryse (2006) that most business operators need to increase their efficiency and productivity.

The results presented in table 3 show that the male and female personnel managers in urban and rural centres differ significantly in their mean ratings on the business operators' efficiency in managerial skills. Thus, null hypothesis was rejected at .05 level of significance. Further attempts were made to find out the direction of their ratings using the Scheffe Multiple Comparism test. The results were presented in table 4. The results show that there is no significant difference among the means of each of the groups compared.

The findings of this study have a number of implications for the manufacturing industries operating in the Anambra. The implications are both practical and theoretical in nature. The industries need to recommend their staff for in-service training programmes, and also encourage them to attend the programmes. The findings also imply the need for the business operators in Anambra state to grow professionally.

\section{Conclusion}

From these findings, the researcher concludes that the business operators lacked some managerial skills necessary for high performance in office.

\section{Recommendations}

Based on the findings of this study, the following recommendations are made:

1) Business operators in Anambra State should attend inservice training programmes on managerial skills to enable them perform efficiently in their business.

2) Business operators should motivate one another and maintain a healthy working relationship with one another in their business areas in order to perform better in their business and as well, improve on their managerial skills.

3) The business operators should assist each other grow professionally through proper guidance in business transactions and in-service training programmes.

\section{References}

[1] Anado, E.O. (2003). Assessment of the implementation of Introductory Technology in Imo State. Unizik Orient Journal of Education. 2(1) 56-64.

[2] Arukwe, O.N. (2000). Employees' office skills competencies and employers' preferences. Business Education Journal 2(2) 111-116.

[3] Boyatzis, R.E. (2010). The competent manager: A model for effective performance. New York: Wiley.

[4] DeCenzo, J.M. (2004). The Role of the TESL Supervisor. Journal of Education for Teaching.

[5] Gomez-mejia, J. R.; Balkin, D.B. \& Cardy, R. L. (2004). Managing human resources. New Jersey Pearson.

[6] Harrison. W. (2002). Clerical office procedures. Chicago. South Weston Publishing Company.

[7] Obikeze, S.O. Obi, E.A. \& Abonyi N. (2005). Personnel Management Concepts, principles and application. Onitsha. Book point Ltd.

[8] Obikeze S. O., \& Obi E.A. (2004). Public administration: A developmental approach. Onitsha: Bookpoint Ltd.

[9] Katz O. A. (2014). Curriculum improvements: A guide to problems, prin-and process. New York, Herpes and Row.

[10] Pryse, B.E. (2006). The perfect secretary. Aylesbury, Sucks. Hazel, Watson and Viney Ltd. 


\section{International Journal of Science and Research (IJSR) \\ ISSN (Online): 2319-7064}

Index Copernicus Value (2013): 6.14 | Impact Factor (2015): 6.391

[11] Ryan, L. (2007). Principles of vocational and technical teacher education. Preparing teachers for tomorrow's workforce. Columbia: University Council for Vocational Education.

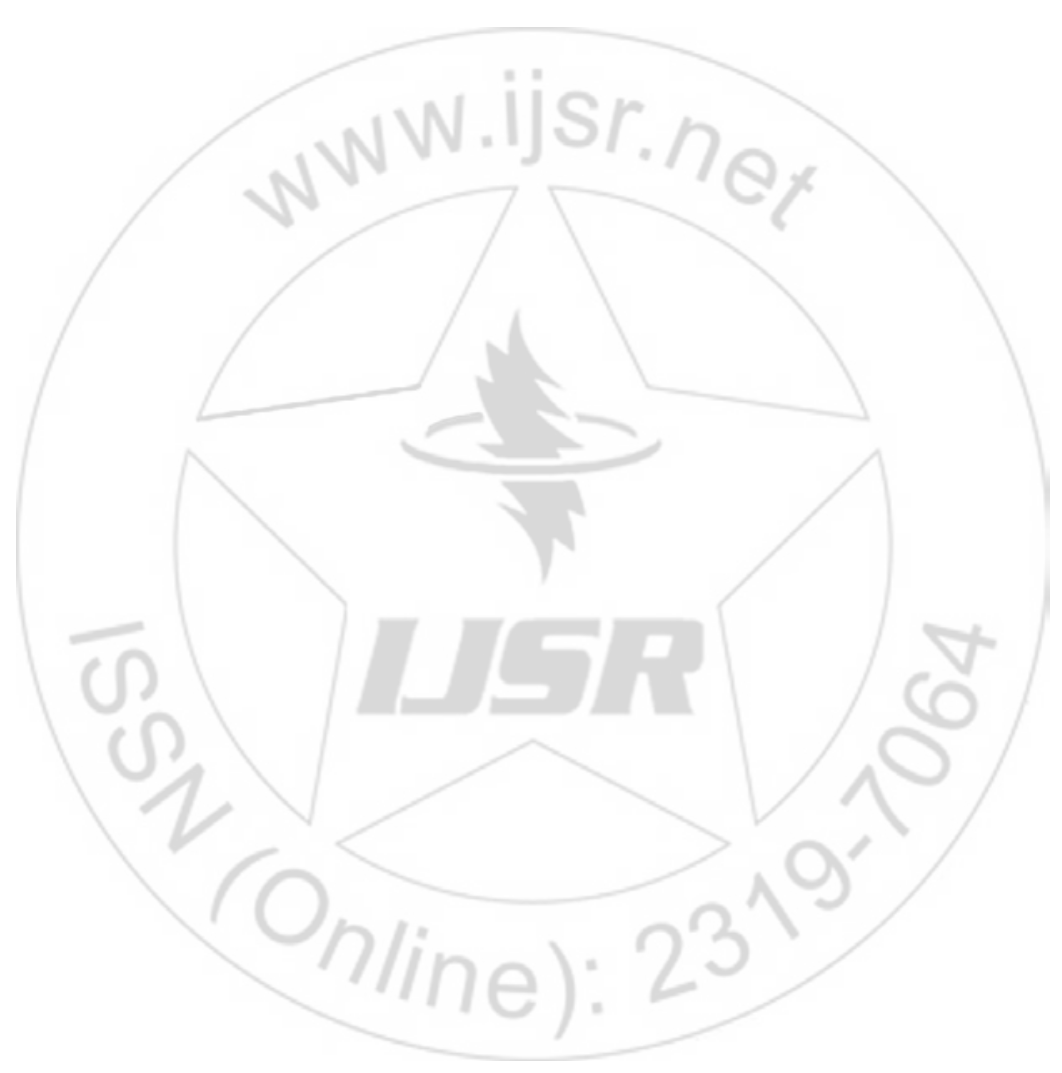

Volume 5 Issue 5, May 2016

www.ijsr.net 